\section{Literacy, Pharaonic Egypt}

KATHARINA ZINN

Literacy, understood as the ability to read and write, was the trigger for and prerequisite of ancient Egyptians entering into a good profession, rank, and high social status, as stated in the "Instruction of Ani," one of the Egyptian wisdom texts: "One will do all you say if you are versed in writings" (Lichtheim 1976: 140). This could happen regardless of social rank at birth, as to rise socially was possible for literate people.

However, what exactly literacy was is difficult to determine in the ancient world. Literacy as a term can describe a wide range of abilities and different levels of reading and writing, from ability to decipher or recognize a few signs called functional literacy - to possession of the full ability of fluent reading and writing of HIEROGLYPHS as well as HIERATIC and/or DEMOTIC. Others could sign documents and were therefore often seen as literate by the ancient Egyptians, but were illiterate beyond that. Furthermore, there were people who were able to read but not to write and perhaps even the other way around. Besides this, there was a wide span of what we would call already literate or still illiterate (Lesko 1990: 657-8). Which ability is required in order to be literate? Potential Egyptian literacy levels range from that of relief sculptors, who could carve stones, but had only a limited reading ability, up to the highest level with the full reading competence and complete capacity to compose texts on their own. In between we have to recognize different stages with various degrees of reading competency, the physical ability to write, and narrow to wider composing capability (Der Manuelian 1999: 286).

However, being not fully literate did not really influence the high regard (semi-)literate people were held in. Village sCRIBEs in rural Egypt might not have been wholly literate, but because of their skills they were definitely at the top of the social ladder in the village hierarchy and therefore prominent, needed, and esteemed by the villagers. Such levels are connected with different registers of language, which influenced the ability to read and write. Tomb workers, living in DEIR EL-MEDINA, could perhaps read texts inscribed in tombs, but might be unable to write legal documents. Others were able to handle hieroglyphs (medu netjer - divine words), but not understand the handwritten versions (hieratic or demotic) and vice versa. All these considerations are difficult enough to weigh if we look at present societies, but even more so, if we concentrate on ancient ones.

It is widely forgotten that Egypt had an oral culture co-existing with the written evidence, because what are preserved are the written documents and monuments. Many texts originated in oral traditions. Nevertheless, the written text doubtless differed from the orally transmitted one. The scribe who wrote the text was able to edit, summarize, and correct the ideas. Transmitting information was now more efficient (Te Velde 1986: 255). This was already perceived by the Egyptians. HATSHEPSUT mentioned in her cult calendar from SPEOS ARTEMIDOS that the festival dates were known (literally: "they were in the mouth," Urk. IV: 388, 17), but remembered at the wrong times. Literacy was highly esteemed. In the Papyrus Chester Beatty IV (Pap. BM EA 10684), we find a eulogy to dead writers, which seems to refer to genuine writers/ authors, who were not forgotten because of their texts. This kind of text, often called The immortality of writer, belonging to the group of school texts, describes books as more durable than stone tombs, and therefore the names of the writers have been remembered (Lichtheim 1976: 175-8).

Even though ancient Egyptian society appears to have changed very little over thousands of years, cultural phenomena like literacy were influenced by geographical, chronological, and sociological factors. The accessibility of education and the possibility to practice acquired skills and knowledge were limited or promoted by factors such as where 
(the capital, town, or rural environment), to which social class (elite or not), and when (which period: literacy in Greco-Roman times was higher than in the third millennium BCE) a person was born. Furthermore, gender and age may have been important. In short, literacy was dependent on the social status of a person, even though there were some exceptions. It seems clear that priests (for correct performance of rituals), and officials of high rank in the military and administration, as well as scribes would have been literate by profession, as these were the privileged jobs for literate people. We would expect the highest rate of literacy in communities set up by the state for the administration of highly prestigious projects, as it is assumed that literacy was often linked to people's occupations. An example is Deir el-Medina, where the skilled tomb workers of the Valley of the Kings and their families lived, and the settlement of Lahun, housing the personnel connected with the building and running of the Middle Kingdom pyramid complexes nearby. In Deir el-Medina, a high proportion of ostraca and papyri are literary, amounting to more than 1,500 texts, and include most of the texts known from Pharaonic times. That is a much higher percentage than usual. Some of the texts are represented by hundreds of examples. In addition, historical, medical, and magical texts as well as dream interpretations have been found (Lesko 1994: 132-3). Scribes such as Kenkherkhepshef owned real archives with all kinds of texts; therefore they have been classified as bibliophiles by Egyptologists. This collection also provides evidence for interconnections between scribes in the Theban area, and it was passed down through several generations. Many of the workmen were able to write their names and may have been able to read, at the very least, their exchanged messages (Lesko 1994: 135-7).

On the other hand, it seems that being illiterate in Ancient Egypt did not mean being uncultured or completely uneducated, as is often the case in modern times. The best examples are the numerous non-literary papyri from the Greco-Roman period in which it is routinely specified that at least one party was illiterate and that a trusted person or a professional scribe wrote or checked the agreement, or subscribed (Kraus 2000: 325-7).

The ancient Egyptians were aware of the difference between being literate or illiterate. Even gods could be both. In the tale of Horus and SETH, тнотн teases his master, the sun god $\mathrm{Re}$, in a letter to the goddess NEITH, as being "beloved of Thoth" and therefore inferior to him due to Re's illiteracy (Lichtheim 1976: 215).

Estimations of literacy range from 1 to 5 percent of the population (Baines 2007: 67, 94) to much higher numbers (Lesko 1994; Janssen 1992), especially in Deir el-Medina (5 percent or above), or even up to 15 percent in urban hotspots like Lahun (Literacy 2003). Regarding historical timescales, we can see that literacy spans a range from 1 percent of the population in the third millennium BCE up to 7 percent in the fourth century BCE (estimated by taking into account the whole population; 6 percent if based on the Egyptian population [Ray 1994: 65]) with some decline, especially in the intermediate periods and rising afterward (Baines 2007: 68). These figures were calculated by focusing on the elite class, based on estimates of population, identified monuments, and known writers. The earliest written records seem to be connected with the funerary domain, appearing as signs on tags (tomb $\mathrm{Uj}$ in Abydos), which were written on large plates of animal bone and then broken down into smaller tags, or larger ones from royal burials (sometimes reused, like one by Narmer found in Cemetery B in Abydos). These tags already show different hands with varying levels of writing skill and therefore different degrees of literacy (Wengrow 2006: 198-207). Continuous texts were written from the 3rd or 4th Dynasties onward, most of them being practical, legal, or administrative. By the end of the Old Kingdom, we also have long religious and magical texts as well as "biographical" inscriptions. Narrowly literary texts appeared during the First Intermediate Period or at the beginning of the Middle Kingdom. Monuments 
increasingly featured writing. The New Kingdom brought popular literary types and many love poems. All this need not necessarily correlate with an increase in literacy rates, but it definitely shows a greater familiarity with texts (Baines 2007: 39-42).

Interestingly, evidence for semi-literate people can be found in erasures and usurpations. During the Amarna time, erasures of the signs of the god's name Amun (Jmn) appeared everywhere. Even though Akhenaten's agent seemed generally to be more hesitant to erase Amun's name within the name of his father Amenhotep III, we sometimes find them there as well. On other monuments we find the hieroglyphs hacked out, even in words other than Amun. The iconoclasts looked out for these specific signs, mistaking them for Amun, and erased them without understanding the surrounding text, showing their illiteracy - or semi-literacy (Der Manuelian 1999: 285-7). Late Period and Persian Egypt had become cosmopolitan, and language as well as literacy has to be seen in this context. Even though Egyptian remained the principal language, with its handwriting (hieratic and demotic) and the monumental hieroglyphs, all the new settlers and immigrants brought in their own tongues. There was of course Greek, but we also see Phoenician graffiti in the temple of Osiris in Abydos and a good deal of Aramaic material. Some of the writers seemed to have been literate in both languages, as we find such cross-writings as the Papyrus Amherst, an Aramaic text written in demotic script (Ray 1994: 56-8). We also have good examples of semi-literacy from this period. There are various dockets, mummy labels, and acknowledgements of tax receipts, which give the impression that this extent of writing ability was sufficient for the job (Ray 1994: 63). In Ptolemaic Egypt, the language of administration and government changed over time from Egyptian to Greek and brought an increase in written material, a new schooling program and - so it seemed - a further increase in literacy levels (Thompson 1994).
We have evidence for female literacy, indicated by titles of female scribes (Female Scribe of the divine Adoratrice Irtyru - 26th Dynasty), even though some of them seem to be ambiguous and could also be interpreted as "cosmetician" (Bryan 1984). The number of literate women was much lower than literate men, but not negligible (Baines 2007: 83-9). Some Letters to the dead were written by women to their deceased husbands or addressed to deceased women, though we cannot say if these women were really literate. PALETTES bearing the names of Maketaten and her sister Meritaten - both daughters of pharaoh Akhenaten - give the impression of being scribal rather than painting palettes, due to the use of only red and black ink as well as writing pens. They might therefore indicate female literacy. Furthermore, we have visual proof of female literacy in the New Kingdom: traditional scribal palettes depicted under women's chairs or their side of a double chair from several Theban tombs - TT84 (Iamnedjeh, holds also a rolled papyrus), 69 (Menna), 162 (Kenamun), 147 (unknown), and 148 (Amenemope). Some of the women with the scribal kit under their chair were also Songstresses of Amun (shemayt net Amun), singers in the Amun-temple (Bryan 1984). Yet, though this connection might be striking, it cannot identify any specific employment of these women. We also have letters by women. The earliest comes from the Old Kingdom (6th Dynasty, Cairo Linen CG 25975) and was written about a probate dispute by a wife with regard to her deceased husband (Lesko 1999: 249).

Another problem is the literacy of the pharaoh. Even though the pharaoh was seen as the highest priest, administrator, and scribe, he is never shown in a squatting position while reading or writing (Te Velde 1986: 256). Nevertheless, this did not necessarily mean that the pharaoh was illiterate; in fact it shows his superior position, as the squatting of the scribe is designated as being inferior. Furthermore, the king's main role was not to write and read (Baines 2007: 80; Morenz 1996: 24-5). 
In the tomb of Senedjem-ib (Old Kingdom, 5th Dynasty), two letters of king DjedkareAsosi are eternalized, one of which states: "His majesty wrote it himself with his two fingers" (Urk. I: 60,9). This is the phrase used to indicate that someone wrote something by his own hand and did not dictate a letter. Sety I also affirmed that "my hand is writing" (KRI I: 118,1). In the Prophecy of Neferti, dating to the early Middle Kingdom, king Sneferu of the 4th Dynasty "stretched out his hand to a box of writing equipment, took scroll and palette and began to put into writing the words of the lector-priest Neferti ..." (Lichtheim 1973: 140), which is a kind of purposeful reversal of status and role of king and lector-priest. We meet the reading king, skilled in library work, in the Abydos stela of Neferhotep, a king of the 13th Dynasty, where it says that "[h] is majesty went to the library (per medjat) and his majesty spread out the writings together with his companions. Then his majesty found the bookrolls of the Osiristemple ..." Princes were educated in schools at court or in the residence together with children of high ranking officials and foreign vassals (Feucht 1995: 229-37). We can conclude this from the Instruction for Merikare, where the future king is asked to open, read, and copy the books of the ancestors and pass on their knowledge. Further on, it is said that he chanted the writings together with other members of the elite (Lichtheim 1973: 99-101). The result of such an education is shown in the temple of Sety I in Abydos, where in the Hall of Ancestors Rameses II, in his role as prince and heir, is holding a papyrus scroll while standing in front of seventy-six cartouches of former kings and is "reading out praises" (Mariette 1869: pl. 43). Less strong as evidence for royal literacy are the two glazed inlaid tiles, maybe belonging to book chests of Amenhotep III and his wife Teye, bearing book names that have been interpreted as "ex libris" of their private royal library. We also have a palette displaying the cartouche of Ahmose, the first pharaoh of the 18th Dynasty, which could have belonged to another person as well.

It is interesting that the scribe statue designates the high status of the owner, rather than describing his daily work as sitting and writing in an office. Even high rank officials such as AMENHOTEP, SON OF HAPU are depicted as scribes in statues, but not in reliefs. There it seems that the real hierarchy is indicated with lower scribes sitting and advanced ones commanding. Nevertheless, the scribe is shown to be inferior while squatting as part of the Egyptian order. Statues of seated scribes are one of the most well-known and easily recognizable object groups of ancient Egyptian art, forming one of the oldest types of statues among the seated and standing figures, known from the Old Kingdom onward and used until the seventh century BCE. The writing (holding a pen in one hand, which is often lost) or reading (both hands on the papyrus) scribe is shown seated on the ground with crossed legs under him or one knee standing up. He is holding a partly unrolled papyrus in his lap. The same postures are shown in two-dimensional paintings and reliefs. The ability to read and write was prerequisite for any office and to be shown as a scribe.

SEE ALSO: Ahmose I; Akhenaten (Amenhotep IV); Amenhotep (Amenophis) I-III; Education, Pharaonic Egypt; El-Lahun; Libraries, Pharaonic Egypt; Literacy, Greco-Roman Egypt; Scribes, Egypt.

\section{REFERENCES AND SUGGESTED READINGS}

Baines, J. (2007) Visual and written culture in Ancient Egypt. Oxford.

Bryan, B. (1984) "Evidence for female literacy from Theban tombs of the New Kingdom." Bulletin of the Egyptological Seminar 6: 17-32.

Der Manuelian, P. (1999) "Semi-literacy in Egypt: some erasures from the Amarna Period." In E. Teeter and J. A. Larson, eds., Gold of praise: studies on Ancient Egypt in honor of Edward F. Wente: 285-98. Chicago. 
Feucht, E. (1995) Das Kind im Alten Ägypten: die Stellung des Kindes in der Familie und Gesellschaft nach altägyptischen Texten und Darstellungen. Frankfurt.

Janssen, J. J. (1992) "Literacy and letters in Deir el-Medîna." In R. J. Demarée and A. Egberts, eds., Village voices: proceedings of the symposium 'Texts from Deir el-Medina and their interpretation': 81-94. Leiden.

Kraus, T. J. (2000) “(Il)literacy in non-literary papyri from Greco-Roman Egypt: further aspects of the educational ideal in ancient literary sources and modern times." Mnemosyne 53, 3: 322-42.

Lesko, B. (1999) “'Listening' to the Ancient Egyptian woman: letters, testimonials, and other expressions of self." In E. Teeter and J. A. Larson, eds., Gold of praise: studies on Ancient Egypt in honor of Edward F. Wente: 247-54. Chicago.

Lesko, L. (1990) "Some comments on Ancient Egyptian literacy and literati." In S. IsraelitGroll, ed., Studies in Egyptology presented to Miriam Lichtheim: 656-67. Jerusalem.

Lesko, L. (1994) "Literature, literacy, and literati." In L. Lesko, ed., Pharaoh's workers: the villagers of Deir el Medina: 131-44. Ithaca.
Lichtheim, M. (1973) Ancient Egyptian literature, vol. 1: The Old and Middle Kingdoms. Berkeley.

Lichtheim, M. (1976) Ancient Egyptian literature, vol. 2: The New Kingdom. Berkeley.

Literacy (2003) [online] [Accessed July 2, 2010.] Available at http://www.digitalegypt.ucl.ac.uk/ literature/literacy.html.

Mariette, A. (1869) Abydos: Description des fouilles executées sur I'emplacement de cette ville. Paris.

Morenz, L. D. (1996) Beiträge zur Schriftlichkeitskultur im Mittleren Reich und in der 2. Zwischenzeit. Wiesbaden.

Ray, J. (1994) "Literacy and language in Egypt in the Late and Persian Periods." In A. K. Bowman and G. Woolf, eds., Literacy and power in the ancient world: 51-66. Cambridge.

Te Velde, H. (1986) "Scribes and literacy in Ancient Egypt.” In H. L. J. Vanstiphout et al., eds., Scripta Signa Vocis: 253-63. Groningen.

Thompson, D. J. (1994) "Literacy and power in Ptolemaic Egypt.” In A. K. Bowman and G. Woolf, eds., Literacy and power in the ancient world: 67-83. Cambridge.

Wengrow, D. (2006) The archaeology of early Egypt: social transformations in North-east Africa, 10,000 to 2650 BC. Cambridge. 